\title{
Representasi Konsep Retorika Persuasif Aristoteles dalam Pidato Ismail Haniyah untuk Umat Islam Indonesia
}

\author{
Ali Fikry ${ }^{1}$ \\ ${ }^{1}$ Jurusan Bahasa dan Sastra Arab, Fakultas Humaniora, Universitas Islam Negeri Maulana Malik Ibrahim, \\ Jl. Gajayana 50, Kota Malang, 65144
}

Penulis untuk Korespondensi/Email: 16310178@student.uin-malang.ac.id

\begin{abstract}
Abstrak - Penelitian ini membahas tentang tentang retorika persuasif dalam pidato Ismail Haniyah untuk umat Islam Indonesia. Tujuan penelitian ini adalah menemukan dan menjelaskan konsep retorika persuasif yang ada pada pidato tersebut. Analisis yang digunakan adalah teori retorika persuasif perspektif Aristoteles. Dalam teori ini terdapat penjelasan terkait retorika yang memiliki tiga jenis, yakni retorika forensik, demonstratif, dan Deliberatif. Prinsip teori ini tercermin dalam konsep The Five Canon of Rhetoric, panduan sekaligus ketentuan yang harus ada dalam pidato persuasif. Kelima ketentuan tersebut berkaitan dengan Inventio/Discovery yang berarti penemuan, Dispositio/Arrangement yang berarti penyusunan, Elocutio/Style yang berarti gaya, Pronuntiatio/Delivery yang berarti penyampaian, dan Memoria/Memory yang berarti mengingat. Jenis penelitian ini termasuk dalam kategori kualitatifdeskriptif dengan menggunakan paradigma interpretatif. Teknik yang digunakan dalam pengumpulan data adalah tonton, simak, dan catat. Seluruh data yang didapat kemudian dianalisis menggunakan model Miles Huberman, yakni pengumpulan data, reduksi data, penyajian data, dan penarikan kesimpulan/verifikasi. Penelitian ini mendapatkan hasil berupa 19 temuan data yang berkaitan dengan retorika persuasif dalam pidato Ismail Haniyah untuk umat Islam Idonesia. Dari seluruh data, 6 di antaranya berkaitan dengan jenis reotika persuasif yang mencakup keseluruhan jenis. Sedangkan 13 sisanya berkaitan dengan konsep Five Canon of Rhetoric berdasarkan perspektif Aristoteles.
\end{abstract}

Abstract - This study discusses persuasive rhetoric in Ismail Haniyah's speech to Indonesian Muslims. The purpose of this study is to find and explain the concept of persuasive rhetoric in the speech. The analysis used is the theory of persuasive rhetoric from Aristotle's perspective. In this theory, there are explanations related to the rhetoric that have three types, namely forensic, demonstrative, and Deliberative rhetoric. The principle of this theory is reflected in the concept of The Five Canon of Rhetoric, a guide as well as a provision that must be present in a persuasive speech. The five provisions are related to Inventio (Discovery), Dispositio (Arrangement), Elocutio (Style), Pronuntiatio (Delivery), and Memoria (Memory). This type of research is included in the qualitative-descriptive category using interpretive paradigms. The techniques used in data collection are watching, listening, and taking notes. All data obtained were then analyzed using the Miles Huberman model, namely data collection, data reduction, data presentation, and concluding. This study obtained results in the form of 19 data findings related to persuasive rhetoric in Ismail Haniyah's speech to Indonesian Muslims. Of all the data, 6 of them relate to the type of persuasive rationale which includes all types. While the remaining 13 are related to the concept of the Five Canon of Rhetoric based on Aristotle's perspective.

Keywords - Five Canon of Rhetoric, Palestine, persuasive rhetoric, speech

\section{PENDAHULUAN}

$\mathrm{R}$ epresentasi merupakan tindak kesadaran yang melibatkan tematisasi atau konseptualisasi untuk membidik obyektivitas, kebenaran atau makna. Representasi pada tataran praktis sangat berkaitan dengan perwujudan. Oleh karena itu representasi juga merupakan prosedur dalam ruang lingkup sosial terkait keterwakilan dan hasil dari proses kehidupan sosial yang berkaitan erat dengan perwujudan [1].

Representasi dalam pelaksanaannya sangat berkaitan erat dengan realitas sosial. Oleh karena itu 
pidato sebagai salah satu bentuk realitas sosial yang mengandung nilai bagi para pendengarnya juga menjadi hal dapat direpresentasikan. Dalam pidato terdapat retorika yang mencakup pemilahan kata, teknik penyampaian, dan nilai yang terkandung di dalamnya.

Pidato sebagai salah satu bentuk penyampaian ide memiliki gaya berbeda dari setiap penuturnya. Hal ini dipengaruhi latar belakang pendidikan, konstruk pemikiran, dan luasnya pengalaman. Perbedaan gaya dan cara penyampaian pidato ini berpengaruh pada khalayak. Tentunya pidato yang disampaikan dengan berapi-api dapat lebih mudah memengaruhi audience untuk mengikuti segala macam seruan. Namun semangat berapi-api ini harus diimbangi dengan kemampuan pemilahan dan penyusunan bahasa yang rapi dan menarik saat didengarkan. Sehingga pada tahap selanjutnya, pidato tidak hanya sekadar wacana hambar sebagai pelaksanaan formalitas belaka, tapi juga seni penyampaian ide yang menuntut adanya pengetahuan mendalam dan luasnya pengalaman bagi sang penutur.

Tahap pemilahan kata dan penguasaan lapangan begitu penting untuk keberhasilan seseorang dalam menyampaikan pesan yang efektif sesuai dengan tujuan yang hendak dicapai. Hal ini menjadi prasyarat yang terus dikaji di kalangan akademisi. Sehingga penguasaan materi dan lapangan menjadi salah satu faktor penentu keberhasilan berpidato [2].

Peneliti memilih Ismail Haniyah sebagai subjek penelitian dengan didasari fakta bahwa dia adalah seorang politikus Palestina yang saat ini menduduki posisi sebagai pemimpin Hamas, sebuah organisasi yang bergerak untuk pembebasan rakyat Palestina dari penjajahan Israel. Sebagai seorang pemimpin dia dibekali keterampilan untuk berpidato dengan lancar dan lugas. Tuntutan untuk memengaruhi publik agar ikut serta membela Palestina membuat pidatonya selalu bersifat persuasif. Kemampuannya untuk memengaruhi khalayak dan mengajak mereka pada gerakan pembelaan rakyat Palestina sudah dibuktikan di berbagai forum resmi.

Retorika dalam pidato adalah hal yang pasti adanya. Aristoteles pun memaparkan bahwa retorika adalah seni yang memiliki nilai-nilai tertentu. Nilai tersebut mencakup kebenaran dan keadilan yang mempunyai kekuasaan dan kekuatan dalam masyarakat. Berkaitan dengan hal tersebut Aristoteles kemudian mempertegas bahwa emosi manusia bervariasi dan hal itu dapat dimanfaatkan oleh seorang orator untuk memengaruhi pendengarnya [3].
Dahulu retorika tidak dipandang sebagai ilmu, melainkan hanya sebagai kecakapan berpidato. Kaum Sofis bahkan memandang retorika sebagai alat untuk memenangkan suatu kasus dengan memilih kata, istilah, ungkapan, kalimat yang dapat menarik perhatian pendengar. Sehingga muncul konotasi agak negatif bahwa retorika hanyalah alat untuk bersilat lidah atau berdebat kusir, dan tidak menampilkan hal-hal yang berguna atau berisi dalam tindak tutur [4].

Kemudian dalam perkembangan selanjutnya, utamanya saat ini retorika sudah dikategorikan sebagai ilmu, tidak lagi hanya berlandaskan pada metode-metode kohersif atau asumsi. Retorika, seperti disiplin ilmu yang lain, dirumuskan melalui proses dan hasil penelitian empiris. Artinya, kebenaran dalam retorika saat ini merupakan kebenaran ilmiah yang sesuai dengan fakta dan mengandung pengetahuan [5].

Kajian retorika memiliki fokus pembahasan tentang tata cara seorang komunikator untuk mengembangkan dan memilih startegi-strategi tertentu dalam upaya menyampaikan pesan kepada komunikan (audience) [6]. Oleh karena itu penentuan strategi menjadi penting tidak hanya agar pidato enak didengar, melainkan juga agar pesan tersampaikan dengan baik. Sebab dalam banyak kasus, pidato justru hanya memiliki dampak hiburan tanpa ada yang membekas dalam hati dan pikiran pendengarnya.

Tidak dapat dipungkiri bahwa kaitan antara retorika dalam ilmu komunikasi dengan isu-isu politik sangatlah erat. Pada tataran praktisnya retorika digunakan oleh para intelektual dan penguasa sebagai alat utama untuk penyampaian ide atau gagasan dan penyadaran terhadap masyarakat. Sebaliknya, masyarakat juga menjadikan retorika sebagai alat untuk manyuarakan aspirasi mereka terhadap penguasa [7].

Awalnya penelitian retorika memang tidak berfungsi sangat luas, hanya mencakup teks tertulis yang dapat dilakukan analisis menggunakan retorika. Namun setelah banyaknya perkembangan teknologi dan media komunikasi, analisis retorika mampu menyentuh dan memainkan peran pada objek yang tersebar di media massa seperti yang terdapat di radio, televisi, film, dan bahkan internet [8]. Maka penelitian ini turut serta mengembangkan khazanah kajian retorika yang tidak mengkaji teks, melainkan tuturan langsung dalam sebuah rekaman pidato. 
Di antara pidato Ismail Haniah yang banyak beredar luas, peneliti tertarik untuk mengkaji sebuah pidato yang dia tujukan untuk umat Islam di Indonesia. Pidato ini disampaikan sebagai tanggapan atas Aksi Bela Palestina yang dilaksanakan pada tanggal 17 Desember 2017 di Monas. Tentunya tidak hanya pujian, pidato tersebut juga berisi muatan-muatan persuasif agar pembelaan terhadap rakyat Palestina tetap terus dilakukan. Atas dasar sifat persuasif itulah teori ini dipilih karena dirasa sangat tepat untuk menjadi pisau analisis terhadap objek yang berupa rekaman pidato Ismail Haniyah.

Penggunaan analisis retorika persuasif berdasarkan perspektif Aristoteles sangat jarang atau bahkan belum pernah sama sekali diterapkan pada pidato oleh tokoh politikus dari Timur Tengah semisal Ismail Haniyah. Atas dasar kelangkaan tersebut peneliti tertarik untuk mencoba menggunakan teori ini. Di samping itu sebagaimana telah disebutkan sebelumnya bahwa teori ini sangat cocok diaplikasikan pada pidato tersebut, karena di dalamnya terdapat pembahasan tentang persuasi dalam suatu tuturan, selaras dengan pidato Ismail Haniyah yang selalu bersifat persuasif.

Konsep retorika Aristoteles memiliki tiga jenis, Forensik, Demonstratif, dan Deliberatif. Kesemua jenis inilah yang berusaha peneliti temukan dalam pidato Ismail Haniyah. Di lain sisi retorika ini juga mengajukan istilah The Five Canon of Rhetoric, panduan sekaligus ketentuan yang harus ada dalam pidato persuasif. Ketentuan sistematis semacam ini yang hanya ditemukan dalam konsep retorika milik Aristoteles menarik perhatian peneliti untuk berupaya menemukan representasinya dalam sebuah pidato.

Maka dapat dipahami bahwa penelitian ini bertujuan untuk memaparkan teknik penyampaian pidato Ismail Haniah dalam sudut pandang teori Retorika Aristoteles. Dan untuk mencapai tujuan tersebut perlu dilakukan analisis mendalam tentang aspekaspek persuasif yang terdapat di dalam pidato. Tentunya analisis konten dan konteks sangat diperlukan agar penerapan teori terhadap objek tidak mengalami miskonsepsi. Sehingga pada penelitian ini pemaparan representasi teori dalam pidato tersebut akan mencakup segala unsur pidato yang berkaitan dengan retorika persuasif baik dari segi jenis-jenisnya dan penerapan konsep utama The Five Canon of Rhetoric.

\section{Retorika Persuasif Perspektif Aristoteles}

Teori Retorika yang masih banyak dipelajari hingga saat ini berpusat pada pemikiran Aristoteles tentang retorika sebagai alat persuasi. Retorika dalam kaitannya dengan nilai persuasif dapat didefinisikan sebagai kemampuan menemukan alat-alat persuasi yang tersedia pada setiap keadaan yang dihadapi. Fungsi ini hanya dimiliki oleh seni retorika [9].

Menurut Richard terdapat tiga jenis Retorika dalam doktrin Aristoteles. Pertama, Retorika Forensik. Merupakan jenis retorika yang berfokus pada sifat yuridis dan mempersoalkan masa lalu untuk menentukan benar atau salahnya suatu perbuatan. Kedua, Retorika Demonstratif. Retorika jenis ini berfokus pada Epikdeiktik, berkaitan dengan wacana pujian dan tuduhan untuk memperkuat sifat baik atau buruk seseorang, lembaga maupun gagasan. Pidato jenis ini bertujuan memuji, menghormati atau bahkan sebaliknya. Ketiga, Retorika Deliberatif. Merupakan retorika yang bermaksud untuk menentukan tindakan yang harus atau tidak boleh dilakukan khalayak. Melalui penjabaran ini dapat disimpulkan bahwa pada teori Retorika klasik, kemampuan retorika lebih banyak dipraktekkan untuk bidang hukum serta kepentingan politik [10].

Menurut Kenneth Burke, dalam [11], teori Aristoteles yang sudah berabad-abad usianya, hingga kini sudah berkembang jauh sebagai bahan studi di universitas. Dikenal retorika klasik hingga retorika modern dan praktek retorika kontemporer yang di dalamnya termasuk analisis atas teks tertulis dan visual. Teori retorika tidak sekedar dipraktekkan dalam bidang hukum dan politik, namun juga menarik perhatian bagi ilmuwan sastra dan bahasa.

Seorang pembicara dalam membujuk khalayak harus mempertimbangkan tiga bukti retoris: logika (logos), emosi (pathos) dan etika/kredibilitas (ethos). Teori Retorika adalah teori yang memberi petunjuk untuk menyusun sebuah pidato atau presentasi yang efektif. Dan efektifitas tersebut dapat diraih dengan menggunakan alat-alat persuasi yang tersedia. Beberapa asumsi dasarnya dapat dicermati dalam tiga perkara berikut: pertama, pembicara yang efektif harus mempertimbangkan khalayak, dalam hal ini terjadi komunikasi transaksional. Agar pidato dapat efektif, perlu dilakukan analisis khalayak sehingga pidato dapat disusun sedemikian rupa supaya pendengar memberi respon seperti yang diharapkan. Kedua, pembicara yang efektif menggunakan beberapa bukti dalam presentasi mereka yaitu cara persuasi, ethos, pathos 
dan logos. Ketiga, kanon retorika, yakni prinsipprinsip yang harus diikuti pembicara, meliputi: penemuan (Discovery), pengaturan (Arrangement), gaya (Style), penyampaian (Delivery), dan ingatan (Memory) [12]

Dalam asumsi ketiga, lima prinsip yang kemudian disebut The Five Canon of Rhetoric [13] dapat dipahami melalui rincian penjelasan satu demi satu. Pada tahap Inventio/Discovery (penemuan), pembicara menggali topik dan meneliti khalayak untuk mengetahui metode persuasi yang paling tepat. Pada tahap ini pula, pembicara menentukan tujuan dan bahan (argumen) yang sesuai dengan khalayak [14].

Tahap selanjutnya adalah Dispositio/Arrangement (penyusunan). Pada tahap ini pembicara menyusun pidato atau mengorganisasikan pesan. Pesan dibagi ke dalam beberapa bagian secara logis. "Susunan berikut ini mengikuti kebiasaan berpikir manusia: pengantar, pernyataan, argumen, dan epilog" [14]. Sebuah pengantar akan menarik perhatian, mendirikan kredibilitas, dan menjelaskan tujuan [13].

Tahap berikutnya disebut Elocutio/Style (gaya). Pada tahap ini, Aristoteles memfokuskan perlakuannya pada kata kiasan (metaphor). Dia percaya bahwa "to learn easily is naturally pleasant to all people" dan "metaphor most brings about learning" [13]. Dengan demikian, rasa bahagia yang menyelimuti setiap orang dan penggunaan kiasan dalam pidato akan memudahkan penerimaan materi dalam pembelajaran. "Aristoteles memberikan nasehat: gunakan bahasa yang tepat, benar dan dapat diterima; pilih kata-kata yang jelas dan langsung; sampaikan kalimat yang indah, mulia dan hidup; dan sesuaikan bahasa dengan pesan, khalayak, dan pembicara [14]."

Kemudian tahap selanjutnya disebut Pronuntiatio/Delivery (penyampaian). Pada tahap ini, pembicara menyampaikan pesannya secara lisan/presentasi [14]. Audiens akan menolak (kurang menerima) penyampaian yang telihat terencana. Sebuah kewajaran adalah persuasi, karena sebuah kecerdasan itu sesuai konteks "artifice just the opposite" [13]. Teknik ini mengarah pada teknik pidato impromptu (mendadak tanpa persiapan matang) atau ekstempore (ada persiapan dan menggunakan out-line). Pembicara juga hendaknya memperhatikan olah suara dan gerakan-gerakan badan, untuk mempertegas apa yang ia bicarakan." Tiga prinsip penyampaian pidato: Memelihara kontak visual atau mental, menggunakan olah vokal, menggunakan olah visual [14].

Tahap terakhir adalah Memoria/Memory (Mengingat). Tahap ini bertujuan untuk menemukan cara bagaimana audiens dapat mengingat isi pesan yang disampaikan. Cara ini berguna untuk mengingat ide dan frasa yang ada dalam pikiran.

\section{METODE}

Adapun metodologi yang digunakan dalam penelitian ini mencakup jenis penelitian, sumber data, teknik pengumpulan data, dan teknik analisis data. Dilihat dari jenis pendekatannya, maka penelitian ini disebut penelitian kualitatif dengan menggunakan teknik analisis isi (content analysis). Dalam penelitian ini peneliti sebagai instrumen kunci memaparkan temuannya dari data yang diperoleh berdasarkan pengamatan tentang nilainilai persuasif dalam pidato Ismail Haniyah.

Dipandang dari sifatnya, penelitian ini merupakan penelitian yang bersifat deskriptif. Penelitian deskriptif sendiri dilakukan dengan melalui teknik survey, studi kasus, studi komparatif, studi tentang waktu dan gerak, analisis tingkah laku, dan analisis dokumenter [15]. Oleh karena itu penelitian ini dimaksudkan untuk menemukan dan mendekripsikan nilai-nilai persuasif dalam pidato Ismail Haniyah.

Selaras dengan apa yang disampaikan Wibowo dalam [16] tentang klasifikasi sumber data, maka pada penelitian ini sumber data dibagi dalam dua kategori, primer dan sekunder. Sumber data primer dalam penelitian ini adalah video rekaman pidato Ismail Haniyah untuk umat Islam di Indonesia yang beredar di Youtube [17]. Sedangkan sumber data sekunder penelitian ini berupa buku-buku dan artikel mengenai teori linguistik, penelitian linguistik, dan teori retorika perspektif Arestoteles.

Teknik pengumpulan data yang digunakan dalam penelitian ini adalah teknik tonton, simak, dan catat. Menonton dalam hal ini merupakan kata lain dari melihat dan menyaksikan objek penelitian [18]. Langkah-langkah teknik tonton yang penulis lakukan adalah menonton pidato Ismail Haniyah untuk umat Islam di Indonesia secara keseluruhan dari awal hingga akhir dan menyaksikan ulang pada bagian yang mengandung nilai-nilai persuasif. 
Kegiatan menyimak dapat dimengerti sebagai keterampilan memahami bunyi-bunyi bahasa yang diucapkan atau dibacakan oleh orang lain dan diubah menjadi bentuk makna [19]. Teknik simak dilakukan oleh peneliti dengan menyimak pidato Ismail Haniyah untuk umat Islam di Indonesia secara keseluruhan dari awal hingga akhir. Kemudian selanjutnya peneliti menyimak ulang dan memindai pidato Ismail Haniyah untuk umat Islam di Indonesia yang berhubungan dengan teori retorika.

Sedangkan teknik mencatat dalam penelitian ini dapat dipahami sebagai kegiatan menulis sesuatu yang dianggap penting dengan bahasa kita sendiri. Mencatat merupakan teknik lain dari meringkas yang membantu pemahaman dan penghafalan [20]. Adapun tahapan-tahapan yang peneliti lalui dalam teknik ini adalah mencatat seluruh kata dan kalimat yang berhubungan dengan nilai-nilai persuasif, mencatat detail kata dan kalimat yang berhubungan dengan nilai-nilai persuasif meliputi pemaknaan secara leksikal, mencatat dan mengkalisifikasi berdasarkan sifat kalimat yang diucapkan, kemudian mencatat dan mengkalisifikasi berdasarkan implikasi dari kalimat yang diucapkan.

Analisis data dalam penelitian ini tidak terlepas dari empat hal penting yang kemudian disebut model Miles dan Huberman. Keempat hal tersebut adalah pengumpulan data, reduksi data, penyajian (display) data, dan penarikan kesimpulan/verifikasi [21]. Pengumpulan data dalam proses analisis data pada penelitian ini dilakukan dengan menyatukan datadata yang sudah didapat dalam satu catatan dengan berbekal piranti elektronik maupun non-elektronik.

Reduksi dilakukan dengan pemilahan data mencakup hal-hal pokok dan membuang yang tidak perlu, lalu memfokuskan data sesuai dengan tema penelitian. Tahapan reduksi ini dilakukan peneliti dengan cara memilah data sesuai tema penelitian, yakni retorika, dan membuang data yang tidak berhubungan dengan teori retorika.

Data yang sudah melalui tahapan reduksi disajikan dalam bentuk tabel yang menjelaskan jenis data dan kategorinya. Tahapan penyajian data ini dilakukan dengan alur menyajikan seluruh data yang sesuai dengan teori retorika lebih dahulu, lalu menyajikan penjelasan atas jenis data yang diperoleh, kemudian menyajikan klasifikasi data berdasarkan kategorinya.
Selanjutnya adalah verifikasi yang dilakukan dengan penarikan kesimpulan atas data yang sudah disajikan. Langkah-langkah dalam verifikasi ini secara berurut dilakukan melalui pengaitan antara data yang sudah disajikan dengan teori retorika, lalu peneliti menarik kesimpulan atas data yang sudah disajikan berdasarkan jenisnya, kemudian pada langkah terakhir dilakukan penarik kesimpulan atas data yang sudah disajikan berdasarkan kategorinya.

\section{HASIL DAN PEMBAHASAN}

Dalam sub ini peneliti menjabarkan temuan data dari objek yang berupa pidato Ismail Haniyah untuk umat Islam di Indonesia. Peneliti mendapatkan dialog yang berhubungan erat dengan konsep retorika persuasif perspektif Aristoteles. Adapun data yang ditemukan berjumlah 19. Pada tahap selanjutnya, data tersebut terbagi pada dua kategori besar, yakni representasi konsep retorika persuasif berdasarkan jenisnya, dan representasi retorika persuasif berdasarkan teori Five Canon of Rhetoric. Berikut adalah penjelasan dari dua kategori tersebut.

\section{Jenis retorika persuasif dalam pidato Ismail Haniyah}

Data yang ditemukan oleh peneliti yang berkaitan dengan jenis retorika persuasif perspektif Aristoteles dalam pidato Ismail Haniyah untuk umat Islam di Indonesia berjumlah 6. Untuk lebih memahaminya dengan baik, perhatikan tabel ringkas berikut:

Tabel 1. Jenis retorika persuasif dan kategori kalimatnya

\begin{tabular}{lll}
\hline Jenis retorika & Jenis kalimat & Jumlah \\
\hline Retorika Forensik & Informatif & 1 \\
Retorika Demonstratif & Pujian & 2 \\
& Celaan & 1 \\
Retorika Deliberatif & Seruan & 1 \\
& Larangan & 1 \\
\hline
\end{tabular}

Melaui tabel tersebut dapat diketahui bahwa representasi atas jenis retorika persuasif dalam pidato Ismail Haniyah mencakup keseluruhan pembagian jenis retorika berdasarkan teori Aristoteles. Data yang ditemukan seluruhnya berupa kalimat. Selanjutnya kalimat ini juga dikategorikan berdasarkan jenisnya. Untuk memahami betul bagaimana bentuk representasi temuan data terhadap teori yang dipakai, berikut adalah penjelasan rinci secara berurutan atas setiap data dalam tabel di atas beserta terjemahan kalimatnya: 
"لأن القس كما هي أولى القبلتين، وثاني المسجدين، وثالث

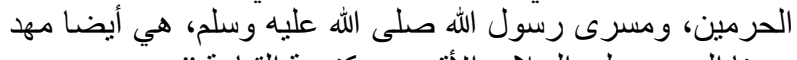
سيدنا المسيح عليه السلام، الأقصى وكنيسة القيامة."

"Karena sesungguhnya Al-Quds sebagaimana di sana terdapat Kiblat pertama, Masjid kedua (yang dibangun), Masjid ketiga yang dimuliakan, dan tempat Isra' Rasulullah SAW, juga terdapat tempat kelahiran Nabi Isa AS, yakni Masjid Al-Aqsha dan gereja Al-Qiyamat.” (Menit 01:39)

Dalam kalimatnya tersebut, Ismail menyampaikan perihal Al-Quds secara historis. Dia menjelaskan posisi Al-Quds dalam dua sudut pandang berbeda yakni Islam dan Kristen. Dan semua yang dia sampaikan berkaitan dengan peristiwa di masa lalu. Maka hal ini jelas menjadi representasi atas jenis retorika forensik perspektif Aristoteles yang mengacu pada peristiwa di masa lalu. Fungsinya adalah untuk menentukan benar atau tidaknya suatu tindakan berkaitan dengan Al-Quds dalam hal ini adalah pernyataan Donald Trump.

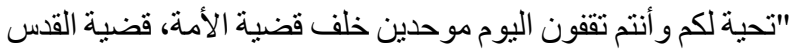

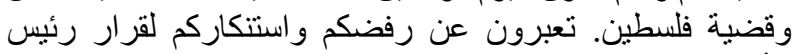
الأمركي تر امب." فلمبن.

"Salam (hormat) kepada kalian saat kalian semua hari ini berdiri seraya bersatu di belakang perjuangan umat, yakni terkait masalah Al-Quds dan Palestina. Engkau sekalian menyatakan penolakan dan ketidaksetujuan terhadap keputusan Presiden Amerika, Trump." (Menit 00:50)

Kalimat di atas adalah bentuk ucapan terima kasih dan pujian atas bersatunya rakyat Indonesia dalam membela Palestina. Ismail sebagai pemimpin yang mewakili rakyat Palestina menunjukkan rasa senang atas sikap peduli rakyat Indonesia. Hal ini menjadi representasi atas retorika demonstratif yang memang memaparkan pujian atau celaan terhadap sifat dan sikap seseorang atau suatu lembaga. Tujuannya adalah menyanjung atau menjatuhkan. Sedangkan dalam kalimat tersebut, Ismail bertujuan untuk menyanjung tindakan rakyat Indonesia.

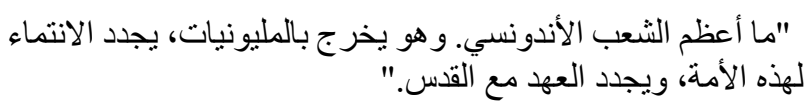

"Betapa hebatnya orang Indonesia. Mereka keluar bersama jutaan orang, memperbarui afiliasi bangsa ini, dan memperbarui perjanjian dengan Yerusalem.” (Menit 02:31)

Kalimat ini juga merupakan bentuk pujian dari Ismail terhadap semangat orang Indonesia dan kesediaan melakukan aksi berjuta-juta Umat dengan turun ke jalan untuk menyuarakan aspirasi bagi
Palestina. Ismail kagum dengan persatuan umat Islam di Indonesia. Sehingga dia menggunakan Ta'ajjubiyyah di awal kalimat ini untuk menunjukkan rasa kagumnya. Pujian yang ditujukan untuk menyanjung ini menjadi representasi atas retorika demonstratif.

كل مسيحي القرار الذي مثل عذه الأرض." على على كل مسلم فوق هذه الأرض، بل

"Keputusan dia (Trump) ini menampakkan permusuhan terhadap setiap Muslim, bahkan juga terhadap umat Kristen di negeri ini." (Menit 01:26)

Dalam kalimat tersebut terdapat upaya pencelaan oleh Ismail atas tindakan Donald Trump. Dia bertujuan menjatuhkan martabat Donald Trump dengan mengatakan bahwa keputusan Presiden Amerika tersebut merupakan bentuk nyata atas upaya permusuhan terhadap umat Islam dan Kristen di Al-Quds. Permusuhan merupakan hal negatif. Maka siapapun yang memicu permusuhan akan dianggap sebagai orang tercela atas upaya tersebut. Oleh karena itu celaan yang bertujuan untuk menjatuhkan ini merepresentasikan retorika demonstratif.

"استمرو !! لا نتوقفو !! زيدوا من فعلياتكم ونشاطاتكم، وليكن شعارنا

“Teruskan! Jangan berhenti! Tingkatkan tindakan dan aktivitas Anda, dan semoga perjuangan kita dapat menjatuhkan keputusan Trump." (Menit 04:03)

Melalui perkataannya tersebut, Ismail mengajak umat Islam di Indonesia untuk terus memperjuangkan hak-hak rakyat palestina. Perjuangan tersebut yang nantinya diharapkan dapat membatalkan keputusan Trump terkait konflik Israel dan Palestina. Kalimat ini merupakan seruan dan ajakan. Maka jelas hal ini merupakan representasi atas retorika Deliberatif yang merupakan jenis retorika berisi seruan untuk melakukan sesuatu.

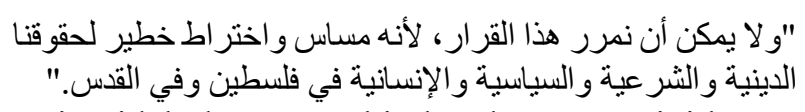
"Kita tidak dapat membiarkan keputusan ini karena ini merupakan pelanggaran berat dan pelanggaran terhadap hak-hak agama, hukum, politik dan kemanusiaan kami di Palestina dan Yerusalem." (Menit 04:14)

Kalimat ini didahului oleh kata yang mengandung makna "Tidak" atau bisa disebut sebagai kalimat negasi. Ismail menyampaikan ketidakmungkinan untuk membiarkan masalah keputusan Trump atas 
Palestina. Sebab hal tersebut merupakan pelanggaran atas banyak aspek, baik hukum, politik, dan kemanusiaan. Negasi/ingkaran akan berimplikasi pada larangan. Maka ketidakmungkinan yang disampaikan Ismail dapat dipahami sebagai sebuah larangan untuk membiarkan masalah ini terus berlanjut. Akhirnya, dapat dipahami bahwa kalimat ini mengandung retorika Deliberatif yang di dalamnya bertujuan untuk melarang suatu perbuatan.

\section{Prinsip Five Canon of Rhetoric dalam pidato Ismail Haniyah}

Data yang ditemukan oleh peneliti yang berkaitan dengan prinsip Five Canon of Rhetoric menurut perspektif Aristoteles dalam pidato Ismail Haniyah untuk umat Islam di Indonesia berjumlah 13. Untuk lebih memahaminya dengan baik, perhatikan tabel ringkas berikut:

Tabel 2. Konsep Five Canon of Rhetoric dan deskripsi

\begin{tabular}{lll} 
& datanya & \\
\hline Jenis retorika & Jumlah & Deskripsi data \\
\hline Inventio/Discovery & 2 & - Mengangkat topik \\
(Penemuan) & & keputusan Trump \\
& yang kontroversial \\
& - Memahami \\
& kondisi rakyat \\
& Indonesia yang \\
& bersimpati
\end{tabular}

\begin{tabular}{|c|c|}
\hline $\begin{array}{l}\text { Dispositio/Arrangement } \\
\text { (Penyusunan) }\end{array}$ & $\begin{array}{l}\text { - Dibuka dengan } \\
\text { pujian } \\
\text { - Menyampaikan } \\
\text { fakta sejarah di } \\
\text { awal pidato } \\
\text { - Menyatakan sikap } \\
\text { di pertengahan } \\
\text { pidato } \\
\text { - Menyampaikan } \\
\text { seruan di akhir } \\
\text { pidato }\end{array}$ \\
\hline
\end{tabular}

\begin{tabular}{ll} 
Elocutio/Style (Gaya) 22 & $\begin{array}{l}\text { - Isi pidato to the } \\
\text { point }\end{array}$ \\
\hline - Banyak memuji
\end{tabular}

$\begin{array}{lll}\text { Pronuntiatio/Delivery } & 3 & \text { - Tanpa catatan } \\ \text { (Penyampaian) } & \text { - Minim gerakan } \\ & \text { tubuh } \\ & - \text { Banyak } \\ & \text { mengandalkan } \\ & \text { kontak mata dan } \\ & \text { intonasi }\end{array}$

\begin{tabular}{lll}
$\begin{array}{l}\text { Memoria/Memory } \\
\text { (Mengingat) }\end{array}$ & 2 & $\begin{array}{l}\text { - Mengulang pujian } \\
\text { - Mengulang seruan }\end{array}$ \\
\hline
\end{tabular}

Melaui tabel tersebut dapat diketahui bahwa representasi atas konsep Five Canon of Rhetoric dalam pidato Ismail Haniyah mencakup keseluruhan tahapan konsep tersebut berdasarkan teori Aristoteles. Data yang ditemukan seluruhnya berupa analisis konten. Maka di bawah ini adalah penjelasan secara rinci atas analisis masing-masing data secara berurutan dalam tabel di tersebut.

Pertama, Inventio/Discovery (Penemuan). Pada prinsip pertama ini, Ismail selaku orator perlu menemukan topik yang sesuai dengan khalayak, dalam hal ini adalah masyarakat Indonesia. Sebagai sebuah pidato yang merupakan tanggapan atas Aksi Bela Palestina, maka Ismail mengangkat tema berupa keputusan kontroversial Trump yang mengakui Yerussalem sebagai Ibu Kota Israel. Tema ini selaras dan senada dengan aspirasi rakyat Indonesia yang memang bertujuan untuk kesejahteraan rakyat Palestina.

Orator juga diharuskan untuk memahami kondisi khalayak yang akan menjadi objek pidatonya. Dalam hal ini Ismail memahami bahwa rakyat Indonesia mudah bersimpati. Sehingga dalam pidatonya dia banyak mengungkapkan aspek-aspek yang mengandung tragedi dan ironi.

Kedua, Dispositio/Arrangement (Penyusunan). Di awal pidato Ismail langsung menyampaikan pujian atas sikap rakyat Indonesia. Hal ini membuat siapapun yang menyimak pidato tersebut akan tersanjung. Sehingga etika pidato semacam ini akan berdampak positif bagi khalayak.

Setelah itu susunan pidato dimulai dengan penyampaian fakta sejarah tentang Yerussalem dan Masjid Al-Aqsha. Hal ini ditujukan sebagai pintu pertama untuk menilai sikap atau tindakan terhadap tempat bersejarah tersebut. Dengan menyampaikan fakta sejarah, maka penilaian atas tindakan terhadap Yerussalem yang dilakukan oleh Trump akan berlangsung objektif.

Selanjutnya di pertengahan pidato mulai nampak sikap yang diambil oleh orator, yakni Ismail terhadap tindakan Trump. Sikap tersebut berupa kecaman. Hal ini terjadi karena fakta sejarah yang menyatakan bahwa Yerussalem dikuasai oleh umat Islam kemudian berlawanan dengan sikap Trump yang mengklaim Yerussalem sebagai Ibu Kota Israel. Kontradiksi antara fakta sejarah dan tindakan Trump inilah yang memunculkan kecaman dari berbagai pihak, tak terkecuali oleh Ismail Haniah. 
Di akhir pidato Ismail menyampaikan seruan sebagai tindak lanjut atas kecaman yang telah dia sampaikan sebelumnya. Seruan tersebut berisi ajakan untuk tetap melangsungkan tindakan dan aksi serupa. Juga terdapat larangan untuk membiarkan keputusan Trump begitu saja. Maka penutupan pidato dengan cara ini akan semakin memberikan dampak nyata dan melekat di hati para khalayak yang menyimaknya.

Ketiga, Elucotio/Style (Gaya). Gaya penyampaian pidato oleh Ismail sangat nampak to the point. Dia tidak lagi bertele-tele dengan menyampaikan latar belakang dirinya ataupun masalah yang akan dia bahas seputar Palestina. Sejak awal pidato dia langsung berterima kasih pada umat Islam di Indonesia dan membahas konflik seputar keputusan kontroversial Trump. Gaya pidato to the point ini digunakan tentunya sebab Ismail tahu bahwa umat Islam di Indonesia sudah menaruh simpati sejak lama terhadap penderitaan rakyat Palestina.

Selanjutnya Ismail seringkali menyampaikan ucapan terima kasih dan pujian untuk menyanjung sikap umat Islam di Indonesia. Sanjungan tersebut disampaikan tidak hanya sekali di awal pidato, melainkan berkali-kali bahkan hingga akhir pidato. Gaya semacam ini memiliki efek emosional yang membuat khalayak yang menyimak pidatonya akan tergugah hatinya.

Keempat, Pronuntiatio/Delivery (Penyampaian). Teknik penyampaian pidato kadangkala berdasarkan outline yang sudah dipersiapkan sebelumnya. Atau juga bisa disampaikan secara spontan tanpa berpedoman pada catatan apapun. Teknik kedua inilah yang nampak digunakan dalam penyampaian pidato oleh Ismail. Sepanjang pidatonya dia benarbenar fokus pada kamera dan tidak nampak membaca. Hal ini memiliki daya tarik tersendiri bagi khalayak yang menyimak pidatonya.

Dia juga menyampaikan pidato dengan tidak banyak menggerakan tubuh. Dia tidak berpindah-pidah tempat atau menggerakkan tubuhnya ke arah lain. Ismail berpidato dengan posisi tegak sejak awal hingga akhir.

Yang menjadi titik tumpu dari teknik penyampaian pidatonya adalah pandangan mata dan intonasi suara. Dia nampak sangat memfokuskan pandangannya pada satu arah. Hal ini membuat siapapun yang menyimak pidatonya merasa seolaholah Ismail sedang berbicara padanya di hadapannya secara langsung. Ismail juga memanfaatkan intonasi suaranya. Pada kalimat yang membutuhkan penekanan khusus, dia meninggikan nada suaranya. Teknik penyampaian pidato dengan cara ini akan sangat menghemat tenaga.

Kelima, Memoria/Memory (Mengingat). Pada tahapan terakhir ini yang menjadi fokus utamanya bukan lagi penutur, melainkan pemirsa. Pidato yang baik adalah pidato yang membekas dan mudah diingat oleh khalayak. Ismail memiliki caranya sendiri untuk membuat pemirsa mengingat pidatonya dengan baik.

Dia menggunakan teknik pengulangan pada kalimat yang memang menjadi inti pidatonya. Kalimat yang dia ulang-ulang adalah pujian. Berkali-kali pujian terhadap umat Islam di Indonesia dia sampaikan. Hal ini menjadi penting karena posisinya sebagai pemimpin Hamas yang harus mengapresiasi segala bentuk kepedulian sosial dari umat Islam di luar Palestina.

Kemudian yang dia ulang-ulang selanjutnya adalah kalimat seruan. Dia menyerukan agar perjuangan tidak berhenti sebatas dalam bentuk aksi turun ke jalan saja, melainkan juga harus dilakukan dengan bentuk lain yang efektif. Agar pemirsa mengingat dengan jelas seruannya, maka dia melakukan pengulangan atas seruan tersebut di pertengahan dan akhir pidato.

\section{KESIMPULAN}

Dalam pidato Ismail Haniyah yang menjelaskan tentang apresiasi atas Aksi Bela Palestina peneliti menemukan data berupa jenis-jenis retorika persuasif dan konsep Five Canon of Rhetoric perspektif Aristoteles. Berdasarkan data yang diperoleh dari pidato tersebut terkait retorika persuasif, jenis retorika yang terkandung di sana mencakup seluruh jenis, yakni forensik, demonstratif, dan Deliberatif. Adapun Five Canon of Rhetoric dapat ditemukan dengan teknik analisis konten terhadap pidato tersebut.

Hasil penelitian ini dapat dijadikan acuan untuk pengembangan teknik berpidato. Sebab retorika persuasif perspektif Aristoteles dalam hemat peneliti tidak hanya dapat digunakan sebagai pisau analisis, melainkan juga bisa digunakan sebagai pedoman yang dapat dimanfaatkan oleh siapapun yang hendak berpidato di depan umum. Dengan mematuhi ketentuan yang tercantum dalam teori ini, pidato yang disampaikan akan sesuai dengan fungsinya dan 
memiliki dampak yang efektif. Sebab teori ini mengajukan banyak ketentuan sistematis yang bisa dipersiapkan sebelum berpidato.

\section{UCAPAN TERIMA KASIH}

Ucapan dan rasa terima kasih saya tujukan pada saudara Ahmad Maki selaku pemilik buku karangan Aristoteles yang memang berjudul "Retorika". Sebab adanya buku tersebut peneliti tertarik untuk membacanya sekilas kemudian tergerak untuk menggunakannya sebagai teori dalam analisis penelitian ini.

\section{REFERENSI}

[1] A. Purwasito, Komunikasi Multikultural, Surakarta: Universitas Muhammadiyah Surakarta, 2003.

[2] A. Kholiq, "KH. Zainuddin MZ (Kajian Teori Retorika Aristoteles)", Jurnal Studi Islam Madinah, vol. 6, no. 2, 2011.

[3] Rajiyem, "Sejarah dan Perkembangan Retorika", Jurnal Humaniora, vol. 17, no. 2, 2005.

[4] I. N. Martha, "Retorika dan Penggunaannya dalam Berbagai Bidang", Jurnal PRASI, vol. 6, no. $12,2010$.

[5] Suardi, "Urgensi Retorika dalam Persfektif Islam dan Persepsi Masyarakat", Jurnal Annida', vol. 41, no. 2, 2017.

[6] E. Natanael, C. Gatot H., "Konstruksi Gaya Retorika Fredrich Yunadi (Analisis Retorika Aristoteles Program Televisi Catatan Najwa Edisi 'Setia Pengacara Setya')", Jurnal SEMIOTIKA, vol. 12, no. 2, 2018.

[7] M. F. Ardiansyah, "Analisis Retorika Basuki Tjahaja Purnama dalam Kampanye Rakyat Pemilihan Kepala Daerah Khusus Ibukota Jakarta di Rumah Lembang 2017 (Kajian Retorika Aristoteles)", Jurnal BAPALA, vol. 5, no. $1,2018$.
[8] F. Husna, "Retorika Simbol Islam pada Akun Instagram Ridwan Kamil", Jurnal Komunikasi Global, vol. 7, no. 1, 2018.

[9] Aristoteles, Retorika, Yogyakarta: Basabasi, 2018.

[10] R. Arends, Learning to Teach: Belajar untuk Mengajar, Yogyakarta: Pustaka Pelajar, 2008.

[11] K. Suhandang, Retorika: Strategi, Teknik dan Taktik Berpidato, Jakarta: Nuansa, 2009.

[12] I. Sutrisno, I. Wiendijarti, "Kajian Retorika Untuk Pengembangan Pengetahuan dan Ketrampilan Berpidato", Jurnal Ilmu Komunikasi, vol. 12, no. 1, 2014.

[13] E. A. Griffin, A First Look at Communications Theory, New York: an imprint of The McGrawHill Companies, Inc, 2012.

[14] J. Rakhmat, Retorika Modern: Pendekatan Praktis, Bandung: Remaja Rosdakarya, 1998.

[15] Suryana, Metodologi Penelitian: Model Praktis Kuantitatif dan Kualitatif, Jakarta: Penerbit Univeritas Indonesia, 2010.

[16] W. Wibowo, Cara Cerdas Menulis, Jakarta: Penerbit Buku Kompas, 2011.

[17] AQL Islamic Center, BREAKING NEWS! Sambutan Ismail Haniyyah Tentang Aksi Bela Palestina $\quad 17.12$ Jakarta, https://youtu.be/vfdfb0e5h20, 2017. (Diakses pada 6 November 2019)

[18] Sukardi, Metodologi Penelitian Pendidikan Kompetensi dan Praktiknya, Jakarta: Bumi Aksara, 2003.

[19] S. D. Martaulina, Bahasa Indonesia Terapan, Yogyakarta: Deepublish, 2018.

[20] F. Olifia, Teknik Mencatat, Jakarta: Elex Media Komputindo, 2013.

[21] A. M. Yusuf, Metode Penelitian Kuantitatif, Kualitatif \& Penelitian Gabungan, Jakarta: Prenada Media, 2016. 